\title{
An Investigation of Learner Autonomy in Turkish EFL Context
}

\author{
Dilek Cakici ${ }^{1}$ \\ ${ }^{1}$ Faculty of Education, Ondokuz Mayıs University, Samsun, Turkey \\ Correspondence: Dilek Cakici, Faculty of Education, Ondokuz Mayıs University, Samsun, Turkey
}

Received: February 10, 2017

Accepted: March 9, 2017

Online Published: March 13, 2017

doi:10.5430/ijhe.v6n2p89

URL: https://doi.org/10.5430/ijhe.v6n2p89

\begin{abstract}
This study investigated the teachers' perceptions as to what extent learners should be involved in decision making processes concerning the general aspects of learner autonomy. The primary aim of the research was to find out learning autonomy perceptions of Turkish prospective teachers of English. It is also aimed to explore the effect of gender on the views held by prospective English as a foreign language (EFL) teachers. To this end, a total of 88 senior students (54 females, 34 males) in the Department of English Language Teaching (ELT) at Ondokuz Mayis University participated in this study. Data were collected by the questionnaire "Learner Autonomy: the Teachers' Views" developed by Camilleri (1997). The obtained data were analyzed and interpreted in the form of percentage level for related items. The results of this study indicated that EFL student teachers seem to be ready to take more responsibility and control for their own learning in certain aspects of learner autonomy, whilst in some other areas they still demand teacher's support and guidance. Furthermore, the results demonstrated that overall males and females held similar views about learner autonomy in EFL context. However, a significant gender-based difference was reported in three items.
\end{abstract}

Keywords: Learner autonomy, Autonomous learning, Teacher's perceptions, Prospective teachers, EFL context

\section{Introduction}

Over the last few decades, most of language researchers have gradually shifted their focus from language centered methods to learner centred methods putting learner as individual into the core of learning process. In addition, with the emergence of the communicative language teaching (CLT) paradigm, the research foci shifted from teacher-centered to learner-centered methods in language teaching contexts. Accordingly, learner-centred methods have reshaped and designed the roles of both teachers and learners, mainly their powers and the authorities. The reflections of cognitive and humanistic views on language learning necessitate to explore ever-increasing numbers of new constructs such as autonomy and an autonomous learner by many scholars and researchers. In that sense, it is worthy to examine the notion of autonomy as an essential topic of research interest offered as a pedagogical boost that provides actual improvement in learning a foreign language (Benson, 2001).

Despite the growth in the number of research studies dealing with autonomy, there remains a great debate as to what autonomy is. As having the complicated nature, autonomy is not easily defined in a single expression (Little,1991). Blin (2004) posits that learner autonomy is a 'multidimensional' concept in different educational settings. The concept of "learner autonomy" was first framed by Holec (1981). He conceptualized autonomy as "to take charge of one's own learning is to have, and to hold, the responsibility for all decisions concerning all aspects of this learning (p.3). According to the influential definition by Little (1991, p. 4) autonomy is essentially a "capacity for detachment, critical reflection, decision-making, and independent action." In a similar vein, Dickinson (1987) defined autonomy as " the situation in which the learner is totally responsible for all of the decisions concerned with his learning and the implementation of those decisions" (p. 11). Benson (1997) stands at the same pole and defines autonomy as "the capacity to take control of one's own learning (p.25), also "the rights of learners within educational systems"(p. 29). Likewise, Benard (1995, p. 1) takes the concept of autonomy as "having a sense of one's own identity and an ability to act independently and to exert some control over one's environment, including a sense of task mastery, internal locus of control, and self-efficacy". Littlewood (1996, p. 427) follows the similar path stating that autonomy is the "learners' ability and willingness to make choices independently".

As a multi-faceted nature of concept, autonomy is considered as developing a sense of independent learning in the context of foreign language learning. Hedge (2000, p. 410) declares that autonomy is "the ability of the learner to take responsibility for his or her own learning, and to plan, organize, monitor the learning process independently of 
the teacher". Furthermore, Nunan (1999) argued that stating explicit and attainable objectives, high motivation, selecting effective choices in tasks, appropriate strategies and techniques to employ, monitoring learning procedures, and making decision about self-evaluation makes learners independent and autonomous learners. Virtually, the basic principle of learner autonomy is that learners are different and they learn in quite diverse ways. Thus, autonomy involves encouraging responsibility among learners by giving choice and developing intrinsic motivation, accepting and providing for learner differentiation, promoting reflective enquiry (Bharathi, 2014, p.3). As Benson (2001, p. 82) suggests that autonomy is not "a method of learning, but an attribute of learner's approach to the learning process".

In essence, learner autonomy is the ability to assume responsibility for one's own affairs or the ability to act in a situation in which the learner is totally responsible for all the decisions related with his learning and carrying out these desicions made by the learner independently and consciously. To this end, Holec (1981) points out the steps taken by autonomous learners as follows: (a) taking control of determining their own learning objectives and aims, (b) defining the contents and improvements of their learning; (c) selecting the methods and techniques to be deployed, (d) monitoring the learning progress, and (e) evaluating what had been learned. In link with aforementioned considerations, autonomous learners are able to set their own learning objectives, choose and employ appropriate learning strategies consciously, also they monitor their use of learning strategies, then they evaluate their own learning process and progress independently (Dickinson, 1993). In a somewhat similar manner, restating the idea made by Dickinson, Little (1991) maintained that as autonomous learners are aware of their individual and educational needs, they determine the objectives and goals for their own learning. Also, they know what is to be learned, how to learn, and the resources available. They check progression of their learning in an efficient way, select suitable methods and techniques to be used, monitor the use of the strategies, techniques and material selected and also evaluate what has been learned. Again, autonomous learners are aware of their strengths and weaknesses, they are willing and motivated to assume responsibility for their own learning. All in all, Candy (1991, p. 459-466) listed basic characteristics of autonomous learners as follows: Methodical and disciplined in their learning, logical and analytical in thinking, reflective and aware of self and self-concept, demonstrate openness curiosity, motivation and flexibility, competent in interpersonal and interdependent areas, persistent, responsible and creative, independent and self sufficient.

It is clearly evident that certain necessary skills to be possessed for being an autonomous learner. Ganza (2008) explains the learner autonomy focussing on the interpersonal dynamics of the teacher-learner context, the interrelational dynamics between teacher and learner deeply influence a learner's capacity to be autonomous. In a similar vein, Yan proposed that it is needed to understand the dynamic relationship between teacher and learner in that "they are interrelated and interactive" (2010, p. 176). It is asserted that autonomy may be developed with the help and support of teachers on the dynamic interdependent framework. From this perspective, it is of vital importance to comprehend roles of the teacher to cultivate learner autonomy in educational settings. The great burdens are placed on teachers to help learners to develop autonomy. Still, it is a matter of debate as to how teachers contribute to foster learners autonomy in EFL context. Therefore, it is needed to clarify the changing teacher roles in the autonomous EFL context.

In that sense, Camilleri $(1999$, p. 36) states the following three roles of a teacher to foster learner autonomy in learning environment: i) The teacher as a manager- The teacher as a manager is able to manage and direct the learner activities. ii) The teacher as a resource person- As a resource person, the teacher tries to provide and makes efforts to design optimal learning conditions for their learners by for example, helping them develop an awareness of learning styles (p. 37). iii) The teacher as a counselor-The teacher as a counselor is able to accompany individual learning process and help leaarners to cope with difficulties meaningfully during learning process (p.38). Benson (2001) notes that the teacher can never teach students how to become autonomous. Instead, the teacher should create the best learning conditions by encouraging and motivating learners to develop their autonomy. By and large, teachers are able to play multiple roles such as learning regulators, study guides, and making available resources in an autonomous learning environment ( Fumin \& Li, 2012). Hedge (2000) claims that the role of a teacher has traditionally been to instruct, transmit, regulate, and assess. At the same time, that of the learner has been to receive and absorb. On the other hand, the teacher in an autonomous context is "a facilitator, an organizer, a resource providing learners with feedback and encouragement, and a creator of learning atmosphere. Briefly, a teacher works as "a guide, a co-operative and an initiator" (Joshi, 2011, p. 16). Similarly, Dam (2008) identifies the teacher's role in an autonomous learning context as "a consultant and a facilitator". Little (2004) proposes that the teacher should act as an observer, an advisor, and a manager in an autonomous classroom. Based on the considerations given above, the teachers should be provided with certain skills to foster autonomy in language classroom. In the autonomous classroom, teachers should assume a facilitator role rather than authoritarian. According to Voller (1997), the teacher 
plays the roles of a facilitator, a counselor and a resource. An autonomous classroom necessitates to transfer of control to the learner, negotiationing process with learners, and self-monitoring the teaching process. As put forward by Dickinson (1992), teachers should highly encourage learners to be independent learners by increasing their awareness. Then EFL teacher should provide opportunities to make use of independent tasks by deployment of effective learning strategies. As Fumin and $\mathrm{Li}$ (2012) averred that teachers should offer proper guidance in monitoring and regulating their own study to cultivate students' autonomous learning skill. Hence, learner autonomy entails teachers to perform as catalysts, discussants, consultants, observers, analysts, facilitators and counsellor to foster autonomy (Little, 1991). In addition, the language teacher is supportive, patient, tolerant, emphatic, open and non-judgmental (Wenden, 1998; Benson, 2001). In the autonomous learning "as learner expertise increases, teacher involvement inevitably decreases" (Hurd, 1988, p. 70). Admittedly, as Kumaravadivelu (2001: p. 548) stated, "autonomous learners deserve autonomous teachers."

Within the changing landscape of English language teaching, learner autonomy has received a great interest from researchers. A vast amount of studies have been carried out regarding the learner autonomy for years but few have dealt with the teachers' perspectives and beliefs on learner autonomy. Accordingly, there is a highly demanding need to expand studies attempting to investigate how EFL teachers perceive learner autonomy. Therefore, this study is considered to fill an important gap in research literature on the learner autonomy perceptions of ELT teachers in the local context. The overarching purpose of this research is to provide insights to students and teachers about autonomy in a FL setting. This research is conducted to assess Turkish EFL teachers' perceptions and views of learner autonomy. As Littlewood (2000) stated that it is a necessity to "re-assess" perceptions of the students in different contexts (p. 34). Like learners' beliefs, it is needed to understand the teachers' potential perceptions on major principles of autonomous learning. Additionally, exploring teachers' beliefs helps to know how they conceptualize their own process of teaching language (Richards, Gallo \& Renandya, 2001). Hence, the main purpose of this study was to investigate the perceptions of Turkish prospective teachers of English about learner autonomy. It is aimed at investigating the perceptions of EFL teachers on the decision making process on the course objectives, course content, material selection, study time-place-pace of lesson, course methodology, learning tasks, classroom management, record-keeping, learning styles, learning strategies, homework tasks, and self-assessment in this research. In addition, it is aimed to explore whether there is a relationship between teachers'views on the learner autonomy and their genders. To this end, the following research questions were formulated:

1. How do EFL prospective teachers perceive learner autonomy?

2. What is the gender effect on these perceptions?

\section{Method}

\subsection{Subjects}

The participants of the study were 88 senior students (54 females and 34 males) attending at Ondokuz Mayis University in the ELT department, Turkey. As for participants, senior ELT students are thought as both learners of English as a foreign language and future teachers of EFL. In that sense, it is highly valuable to investigate their perceptions from the EFL teachers' point of views as future teachers of English.

\subsection{Instrument}

In this research, the questionnaire "Learner Autonomy: the Teachers' Views" developed by Camilleri (1997) was used to collect data. The questionnaire was developed for a research to find out language teachers' attitudes towards learner autonomy in different countries as follows: Malta, The Netherlands, Belorussia, Estonia, Poland, and Slovenia. The questionnaire consists of 13 items which are to be responded by using a five-point rating-scale format ranging from not at all to very much. Each question item in the questionnaire has also sub-categories. The questionnaire is designed to explore teachers' perceptions about how they assess the learner involvement from essential aspects of learner autonomy. The items in the questionnaire investigated the views of teachers about learners' involvement in decision making process regarding the course objectives; course content; material selection; course time, place and pace; methodology of the lesson; learning tasks; classroom management; record-keeping; homework tasks; learning strategies; and self assessment. The Cronbach Alpha was reported to be .88 for the present study which manifested a satisfactory reliability.

\subsection{Procedure}

The present study adopted a descriptive kind of general survey research design with a quantitative method. The research was conducted at Ondokuz Mayıs University in the spring term of 2015-2016 academic year. The subjects of the study were chosen randomly and they all participated in the research voluntarily. The analysis of data was 
generated using SPSS (Version, 22.00). Collected data was analyzed by descriptively (mean, scores, frequencies, standard deviations, and percentages) to test research problems. In order to determine gender effect on learner autonomy items, an independent t-test was conducted. Accordingly, the frequencies are analyzed, and the results were given as percentages in the following tables. Two positively worded points (agree and strongly agree) and two negatively worded points (disagree and strongly disagree) were grouped together to see whether the subjects had positive or negative views on one item as for data categorization.

\section{Results and Discussions}

The present research attempted to investigate teachers' perceptions about how much learners should be involved in desicion making process in particular various aspects of learner autonomy. The main purpose of this study is to find out learning autonomy perceptions of Turkish prospective teachers of English. In addition, this survey aims to assess the influence of gender on teachers' views. The first research question investigated how EFL prospective teachers perceive learner autonomy. Table 1 displays only the most outstanding results referring to the positive perceptions of EFL teachers on learner autonomy in percentages.

Table 1. Prospective teachers' positive perceptions on learner autonomy.

\begin{tabular}{|c|c|c|c|c|}
\hline $\begin{array}{l}\text { Item } \\
\text { no }\end{array}$ & Item name & Subtitle & $\begin{array}{c}\text { Much+ } \\
\text { Very Much \% }\end{array}$ & $\mathrm{X}$ \\
\hline 11 & Learning Styles & & 87.4 & 4.33 \\
\hline 12 & Learning Strategies & & 81.1 & 4.20 \\
\hline \multirow{3}{*}{13} & \multirow{3}{*}{ Assessment } & a)weekly & 63.3 & 3.80 \\
\hline & & b)monthly & 67.3 & 3.80 \\
\hline & & c)annually & 56.9 & 3.53 \\
\hline \multirow{3}{*}{8} & \multirow{3}{*}{ Record-Keeping } & a)of work done & & \\
\hline & & b)of marks gained & & \\
\hline & & c)attendance & 65.2 & 3.63 \\
\hline \multirow{3}{*}{10} & \multirow{3}{*}{$\begin{array}{l}\text { What is to be } \\
\text { learned from } \\
\text { materials }\end{array}$} & a)textbooks & & \\
\hline & & b)AVA & 56.8 & 3.77 \\
\hline & & c)realia & 60.0 & 3.77 \\
\hline \multirow{4}{*}{5} & \multirow{4}{*}{ Methodology } & $\begin{array}{l}\text { a)ind./pair/group } \\
\text { work }\end{array}$ & 55.8 & 3.49 \\
\hline & & b)use of materials & 57.8 & 3.61 \\
\hline & & $\begin{array}{l}\text { c)type of class } \\
\text { activities }\end{array}$ & 55.8 & 3.58 \\
\hline & & $\begin{array}{l}\text { d)type of homework } \\
\text { activities }\end{array}$ & & \\
\hline \multirow{3}{*}{3} & \multirow{3}{*}{ Selecting Materials } & a)textbooks & & \\
\hline & & b)AVA & 54.7 & 3.47 \\
\hline & & c)realia & 56.8 & 3.60 \\
\hline \multirow{2}{*}{1} & \multirow{2}{*}{ Objectives } & a) short-term & & \\
\hline & & b) long-term & 52.7 & 3.63 \\
\hline
\end{tabular}

The findings in Table 1 indicate that senior students largely agree to take responsibilities and make most of the decisions about their learning in almost every aspect of autonomous learning in Turkish EFL setting. On the whole, future teachers of English largely reported their willingness to take part in desicion making process independently in language learning progress especially in learning styles, learning strategies, assessment, record-keeping, what is to be learned from materials, methodology, material selection, and objectives of the course.

According to Table 1, senior students largely agree to take responsibilities and make most of the decisions about their learning in almost every aspect of autonomous learning in EFL setting. By and large, the prospective teachers support the idea highlighting the involvement of learners in the process of language learning. Namely, ELT teachers 
extremely appreciated the value of learner autonomy in general. This finding of current study is also consistent with the previous researches: Yumuk, 2002; Özdere, 2005; Al-Shaqsi, 2009; Balçıkanlı, 2010; Borg and Al-Busaidi, 2012; Al Asmari, 2013; Duong and Seepho, 2014; Er, 2014; Salimi and Ansari, 2015.

EFL prospective teachers seem to be ready to give more responsibility to the learners in their own learning process. Teachers generally agreed on the idea that the learners take control for their own learning in certain aspects of learner autonomy, whilst in some other aspects they call for teacher's support and guidance. By the way, it is needed to limit the interpretations to the most salient research findings presented in Table 1.

Noticeably, based on the results of the study, it was reported that item $11(87.4 \%)$ and item $12(81.1 \%)$ attracted the strongest approval from prospective teachers. According to teachers, the basic aspect of learner autonomy is pertaining to learning styles and strategies. It is inferred from that teachers are aware of the necessity for employment different types of learning strategies and also agree that each student should be provided opportunity to use his own learning strategies. They should be given chance to discover how to think and how to find and manage his way to perform classroom tasks. The students will choose his own way and find the appropriate solutions to his problems in this way (Little, 1991; Wenden; 1991; Cohen, 1998). Nunan (1999) argued that "selecting effective choices in tasks, appropriate strategies and techniques to employ"makes learners independent and autonomous learners. Dickinson (1993), autonomous learners are able to choose and employ appropriate learning strategies consciously The result implies that the learners should be provided opportunities to use their learning strategies. Additionally, it appears that a large majority of teachers agree that learners should be involved in decisions on learning process by themselves (item 12). These findings related to two items are in harmony with relevant previous studies (Camilleri, 1997; Özdere, 2005; Er, 2014). As it is stated in literature, learning strategies play crucial roles to cultivate learner autonomy. Language learners need to be trained in learning strategies to foster their potential autonomy. According to Oxford, learning strategies are ".... specific actions taken by the learner to make learning easier, faster, more enjoyable, more self directed, more effective and more transferable to new learning situations"(1989, p.8). One of the main tenets of self-directed learning is learner autonomy. By the way, the probable relationship between learning strategies and their underlying learning styles is searched by many scholars. The students learning preferences may define their use of learning strategies. Also, Oxford (2001) highlighted the harmony between language styles and strategies. Language learners show and develop their ability as independent learners by employing their language learning strategies and/or engaging in independent work, creating their personal learning contexts and/or expressing their personal meanings also evaluate its effectiveness.

Another facet of learning autonomy is concerning assessment. It may be suprising that teachers highly support learner involvement in the process of self-assessment rather than be tested. The teachers agree on that learners prefer monthly and annually self assessment rather than be tested. In essence, Holec (1981) asserts that autonomous learner takes responsibility for evaluating what has been learned. Item 13 asked teachers for their perceptions about self-assessment and testing. In item 13B, $67.3 \%$ agreed on monthly self-assessment rather than for testing; in item 13C, 59\% considered that learners preferred to assess themselves annually rather than be tested. This finding of current study is parallel with the previous studies in the literature (Özdere, 2005; Balçıkanl1, 2010; Bullock, 2011; Er, 2014). As Holec (1979) remarked that an autonomous learner evaluates what has been acquired (p. 3). Autonomous learners should monitor their own learning and assess himself. Cotterall (1995, p. 199) declared that "it is essential that learners be able to evaluate the quality of their learning. An appreciation of their abilities, the progress they are making and of what they can do with the skills they have acquired is essential if learners are to learn efficiently". In contrast, Duong and Seepho (2014) found that the participants disagree on the students' ability relating to self-assessment. Their study indicate that the students lack the capacity for self-assessment in monitoring their own language learning process. The teachers never or sometimes provided opportunities for students to evaluate their own learning. Briefly, depending on the findings regarding 11,12, 13 that are the most salient results of the present study, it is maintained that EFL teachers are willing to give the responsibilities to the students.

The findings represent that a significant portion of teachers $(65.2 \%)$ showed agreement on the decision about record-keeping attendance (8C). Keeping records help gradually learners to raise develop metacognitive control of the learning process, regulate learning process, assess his weakness and strengthness, and also raise their conscious awareness of the language (Little, 2000; Dam, 1995). The learners are expected to record how they progress in the target language. Also, the record-keeping leads the learner to reflective and metacognitive process which is highly significant factor in learner autonomy. Record-keeping offers students the possibility to plan, monitor, and evaluate their learning progress. In that sense, learners gradually become aware that a growing capacity for metacognitive control. Accordingly, the students with a high meta-cognitive awareness necessary for fostering learner autonomy are able to address their weak points easily and also take suitable precautions (Little, 1991). 
Item 10 asked teachers for their views about decisions on what is to be learned from materials given by the teacher. In $10 \mathrm{C}, 60 \%$ of teachers opted for realia; $56.8 \%$ strongly agreed to learn from audio-visual aids in 10B.

Similarly, item 5 dealing with another aspect of learner autonomy entitled classroom methodology. Specifically, a large majority of teachers (57\%) had similar beliefs about choosing individual/pair/group work in item 5B. Furhermore, they agreed that students should be much involved in decisions on the use of materials (5A) and type of classroom activities (5C) with a remarkable support (55.8\%) respectively. This finding implies that the teachers thought that their future students take great responsibilities to themselves related to methodological aspect of learning. The present study reconfirmed that the learner should be taken part in the decisions related to methodological aspects of learning. This finding of current research is parallel with that of numerous studies (Camilleri, 1997; Balçıkanlı, 2010; Yıldırım, 2005; Er, 2014).

Item 3 is the question about learner involvement in the selection of materials. Teachers strongly agreed that learners should be very much involved selecting realia $(56.8 \%, 3 \mathrm{C})$ and audio-visual aids $(54.7 \%, 3 \mathrm{~B})$. The possible explanation for that finding is that teachers agree to adopt principles of learner autonomy in cases related to selection of materials. An autonomous learner has the capacity to decide what materials may assist them in attaining pre-determined learning goals. Furthermore, they may need teachers' support and guidance in selecting proper materials in their own learning (Little, 1991; Dam, 1995). Learners refuse to take more responsibility of choosing textbooks as they still see the teacher as a single authority making desicions about students' learning. For that reason, the students consciously decide to use realia and audio-visual aids matching their own needs, interests, learning styles and strategies (Little, 1991; Dam, 1995; Finch, 2000). Although, coursebooks are core material in foreign language teaching, these supported materials provide learners to monitor their progress and evaluate independently their progress (Little, 1991; Dam, 1995).

Another item 1B on which a vast majority of prospective teachers $(52.7 \%)$ had a similar belief was that the learner should be much involved in decisions related to determining the long-term objectives of a course. Rubin and Thompson (1994) stated the necessity of determining the learners' own objectives. This finding of present study is not in line with previous related studies. Gao and Zhang (2011) averred that students seldomly set their goals on a long term basis. Once again, $\operatorname{Er}(2014)$ reported that the teachers are highly willing to involve in establishing the objectives of the course rather than students.

It is also needed to highlight the most prominent results referring to the negative perceptions of teachers on the involvement of learners in desicion making process. The findings obtained are presented in Table 2.

Table 2. Prospective teachers' negative perceptions on learner autonomy.

\begin{tabular}{|c|c|c|c|c|}
\hline Item no & Item name & Subtitle & $\begin{array}{c}\text { Not at all+ } \\
\text { Little } \%\end{array}$ & $\mathrm{X}$ \\
\hline & & a)quantity & & \\
\hline \multirow[t]{3}{*}{9} & Homework Tasks & b)type & 27.3 & 3.13 \\
\hline & & c)frequency & 36.8 & 2.87 \\
\hline & & a)textbooks & 35.8 & 2.94 \\
\hline \multirow[t]{3}{*}{3} & Selecting Materials & b)AVA & & \\
\hline & & c)realia & & \\
\hline & What is to be & a)textbooks & 32.6 & 2.95 \\
\hline \multirow[t]{3}{*}{10} & learned from & b)AVA & & \\
\hline & materials & c)realia & & \\
\hline & & a)time & 30.5 & 3.00 \\
\hline \multirow[t]{3}{*}{4} & Course & b)place & 24.2 & 3.25 \\
\hline & & c)pace & & \\
\hline & & a)of work done & & \\
\hline 8 & Record-Keeping & $\begin{array}{l}\text { b)of marks gained } \\
\text { c)attendance }\end{array}$ & 28.5 & 3.09 \\
\hline
\end{tabular}


Table 2 indicates that EFL teachers agree on little involvement in particular aspects of learner autonomy. Namely, teachers are resistant to support the involment of learners in teaching and learning activities as follows: decisions on the quantity of homework tasks (9C; $36.8 \%)$, type of homework tasks $(9 \mathrm{~B} ; 27.3 \%)$, selecting textbook $(3 \mathrm{~A} ; 35,8 \%)$, decisions on what is to be learned from textbook $(10 \mathrm{~A} ; 32.6 \%)$, decision about time of the lesson $(4 \mathrm{~A} ; 30.5 \%)$ and place of the lesson (4B; $24.2 \%$ ), decision about record-keeping of marks gained $(8 \mathrm{~B} ; 28.5 \%)$. This finding of current research is consistent with previous studies (Camilleri, 1997; Yumuk, 2002; Özdere, 2005; Balçıkanl1, 2010). All have reached the conclusion that most of student teachers did not appear to welcome learner involvement in decisions related to items stated previously above. The teachers do not favor involvement of their future students in the decision making process concerning particular items. In light of the findings, such resistance may be due to the centralized school system, or the mental culture of teacher or learner (Camilleri, 1997). The participants belive in that time and place of the lesson are fixed by administration. Since, there is a centralized administration in our country, making decision on time and place of lesson are the administrative issues in Turkish education system. As far as textbook selection is concerned, teachers probably seem to limit learner autonomy. Textbooks are prescribed nationally especially in state schools. For that reason, teachers all know that there is no chance to choose textbooks by teachers themselves. Similarly, teachers do not perceive the possibility of involving learners in decision about record-keeping of marks gained. In essence, it is considered to be the teacher's responsibility. Moreover, it is another interesting finding that teachers are resistant to involvement of learners in desicions on both quantity and type of homework tasks. Admittedly, teachers embark on new roles in the autonomous classroom. Teachers play a facilitator, an organizer, a manager in an autonomous learning context. In a general sense, teachers organize a diverse classroom activities to improve their progress, and promote students' actual participation in language learning. Meanwhile, meaningful and suitable homeworks encourage learners to deploy learning strategies and learning styles conciously and independently, also develop the sense of self-discipline and responsibility of working individually. One possible explanation for this finding may be that future teachers of English believed that it is duty of teacher to plan and give purposeful, challenge, clear homeworks or tasks matching students' personal and learning needs. All in all, EFL teachers refuse to share their instructional responsibility in their teaching environments

The second research question examines whether there is a significant relationship between gender and teachers' views about learner autonomy. The items in learner autonomy questionnaire were analyzed and the items which revealed statistically significant differences between males (34) and the female students (54) were stated in Table 3. In this table, the mean analysis of student perceptions about learner autonomy and its relationship with gender was represented. The related findings are delineated in Table 3.

Table 3. Independent t-test results for learner autonomy and gender

\begin{tabular}{lllllllll}
\hline $\begin{array}{l}\text { Item } \\
\text { number }\end{array}$ & Item name & Gender & $\mathrm{N}$ & Mean & $\mathrm{SD}$ & $\mathrm{df}$ & $\mathrm{t}$ & $\mathrm{p}$ \\
\hline \multirow{2}{*}{ 2A } & Course & Females & 54 & 3.31 & 1.07 & 86 & -2.239 & $.028^{*}$ \\
& Content/topics & Males & 34 & 3.82 & .986 & & & \\
\hline \multirow{2}{*}{$9 \mathrm{~A}$} & Homework & Females & 54 & 2.75 & .970 & 86 & -3.449 & $.001^{*}$ \\
& Tasks/quantity & Males & 34 & 3.47 & .895 & & & \\
\hline \multirow{2}{*}{$9 \mathrm{~B}$} & Homework & Females & 54 & 2.68 & 1.078 & 86 & -1.998 & $.049^{*}$ \\
& Tasks/type & Males & 34 & 3.15 & 1.018 & & & \\
\hline
\end{tabular}

As it is viewed in Table 3, male students had higher mean in three items of learner autonomy than that of female counterparts. The results of the independent $t$-test show that this difference is highly significant $(p<0.05)$. Based on the statistical analysis, it is reported that the teachers' perceptions of learner autonomy significantly differ by gender in three items of questionnaire. Namely, it is stated that male students agreed that learners should be much involved in decisions the course content in terms of topics $(2 \mathrm{~A} ; 3.82)$, decisions on the quantity of homework task $(9 \mathrm{~A} ; 3.47)$, and type of homework tasks (9B; 3.15). However, it is observed that female teachers had lower mean than male teachers in previously stated items $(2 \mathrm{~A} ; 3.31), 9 \mathrm{~A} ; 2.75,9 \mathrm{~B} ; 2.68)$. This finding points out that most of the females demanded the teacher's support to decide course topic, quantity and type of homeworks.

In the current research, it is also aimed to investigate whether gender affects teachers' views or not in the current research. The results showed a significant relationship between gender and teachers' perceptions of learner autonomy. A significant gender-based difference was observed in three items in favour of males. A vast majority of males 
believed that the quantity and types of homework tasks are the facets of learner autonomy in which learners are involved. Namely, they have highly positive attititudes towards quantity and types of homework than females. This finding implied that males are more likely than females to believe that quantity and type of homework are two facets of learner autonomy that they actively take part in decision making process. In addition, males and females differed in item 2A which indicated that the learner should be involved in deciding the course topic. The males had higher mean (3.92) than females (3.02). Most of the males agreed with that item; however, females disagreed. This finding of current research is parallel with that of Üstünlüoğlu's (2009) study. In contrast, the finding is not compatible with similar studies examining the effects of gender on learner autonomy (Al-Shaqsi, 2009; Oğuz, 2013; Al Asmari, 2013; Khezerlou, 2013; Er, 2014; Baylan, 2007). This meant that females demanded the teacher's support and they evidently reported that it is teachers' responsibility to decide course topic, quantity and type of homework given to the students. It is inferred from related finding that females are reluctant to take full responsibility to decide on three previously stated items. Also, the female participants still perceive teachers as a single authority figure in the teaching setting. The students perceive teachers as an authoritarian because students call for teacher's directions to perform almost all activities both inside and outside the classroom (Duong and Seepho, 2014).

The present study declared that Turkish female students still are dependent on a teacher for guidance. This finding of study also confirms Aoki and Smith's (1999) remark underlying "autonomy does not entail total independence" (p. 22). On the contrary, Benson (2001) asserts that autonomy entails "the situation in which the learner is entirely independent of teachers, institutions or specially prepared materials" (p. 13). Admittedly, it is put forward that social context and educational systems affect the development of awareness of learner autonomy. Yildirım (2012) maintained that the students may be affected by their cultural and educational background. Therefore, they believed that the teacher has the greatest responsibility in almost all aspects of language learning. In a similar vein, Turkish educational system is likely to perceive the teacher as a dominant figure. In other words, the teacher is assumed to be the most influential factor hindering learner autonomy. Undoubtedly, the teacher should provide learners necessary opportunities through learning practices both in and out of classroom to promote learning autonomy. In general sense, it is widely claimed that the teachers in Turkey are trained in almost similar authoritarian education system, and they were resistance to change their teaching habits (Erdogan, 2003). In line with the same advocacy, Üstünlüoğlu (2009) averred that language learning is contextspecific and is perceived differently in different cultures. Turkey's educational system is not greatly different from those of other eastern countries. The policies of the Higher Education Institution and Ministry of Education leads to an exam-oriented system aiming at training students for proficiency exams and focusing on only grammar use, reading comprehension and writing skills in English teaching. However, Sert (2006) stated that it is not unrealistic to expect to achieve autonomous language learning in more teacher-dominant contexts such as Turkey, even though its successful implementation may take longer. In essence, learner autonomy is fostered by the help of responsibility change between teachers and learners (Balçıkanlı, 2006). Little (1994: 81) claims that autonomy is not a synonym for self-instruction; and also autonomy is not limited to learning without a teacher. In brief, autonomy does not entail an abdication of responsibility on the part of the teacher; it is not a matter of letting the learners get on with things as best they can in educational settings.

\section{Conclusion and Recommendations}

Although a great numbers of research has been conducted on learner autonomy as a multidimensional concept in EFL contexts, the studies especially dealing with teacher's perceptions and perspectives about learner autonomy are quite limited. Therefore, the researcher aimed to explore EFL teachers' perceptions and understandings of learner autonomy in a learner-centered pedagogy. It is expected that this research paved the way for further research on autonomy and FLL. Namely, the current study provides a strong basis for a depth understanding how teachers assess the notion of learner autonomy. Overall, the almost all aspects of autonomous learning principles received full support from the participants. Also, there is a statistically significant difference among the teachers' views based on gender. The conclusions that can be drawn from the findings of this research is that prospective teachers of English are willing to take more control of particular aspects of language learning, while they still demand the teacher's support and guidance in certain areas of learning process. From this perspective, it is put forward that both teachers and learners should agree on sharing responsibilities on the facets of learner autonomy. The teachers should develope good rapport with their learners. Undoubtedly, teachers and students play significant roles and have great resposibilities in promoting autonomy. It is theoretically assumed that the students should perceive themselves as autonomous learners and also teachers should hold positive views about learner involvement in teaching process to design an ideal language teaching environment. What it is suggested is that teachers should become less of an instructor and should act as more of a facilitator, an advisor or a consultor to make the students more autonomous language learner by creating a supportive learning atmosphere. The low control but high support from teacher make 
learners more autonmous. The students should be encouraged and provided with the skills to foster to make decisions about what they learn. It is highly recommended that learner autonomy concept should be included in EFL teaching program. EFL teachers should be involved in the pre-service and inservice training programs on how to appreciate the value of learner autonomy and support their learners to become autonomous learner and to enhance learner autonomy awareness among their learners. Namely, EFL teachers should be provided with some necessary skills to cultivate learner autonomy principles appropriately. Teachers should know their learners' needs and interests, also design effective language activities and tasks using suitable material(s) by negotiating with the learners to take greater responsibilities to improve their language learning.

\section{References}

Al Asmari, A. (2013). Practices and Prospects of Learner Autonomy: Teachers' Perceptions. English Language Teaching, 6(3), 1-10. https://doi.org/10.5539/elt.v6n3p1

Al-Shaqsi, T. S. (2009). Teachers' beliefs about learner autonomy. In S. Borg (Ed.), Researching English language teaching and teacher development in Oman (pp. 157-165). Muscat: Ministry of Education, Oman.

Aoki, N. \& R. Smith (1999). Learner autonomy in cultural context: the case of Japan. In D. Crabbe and S. Cotterall (Eds.), Learner autonomy in language learning: Defining the field and effecting change (pp.19-27). Frankfurt: Lang.

Balçıkanlı, C. (2006). Promoting learner autonomy through activities at Gazi University preparatory school (Unpublished M.A. Thesis, Gazi University, Ankara). Retrieved from http://tez2.yok.gov.tr/

Balçıanlı, C. (2010). Learner autonomy in language learning: student teachers' beliefs. Australian Journal of Teacher Education, 35(1), 90-103. https://doi.org/10.14221/ajte.2010v35n1.8

Baylan, S. (2007). University students" and their teachers' perceptions and expectations of learner autonomy in EFL prep classes (Unpublished M.A. Thesis, Marmara University, İstanbul). Retrieved from http://tez2.yok.gov.tr/

Blin, F. (2004). CALL and the development of learner autonomy: Towards an activity-theoretical perspective. ReCALL, 16(2), 377-395. https://doi.org/10.1017/S0958344004000928

Benson, P. (1997). The philosophy and politics of learner autonomy. Autonomy and Independence in Language Learning, 7, 18-34.

Benson, P. (2001). Teaching and researching autonomy in language learning. London: Longman.

Borg, S. \& Al-Busaidi, S. (2012). Learner autonomy: English language teachers' beliefs and practices. ELT Journal, $12(7), 1-45$.

Benard, B. (1995). Fostering resilience in children. Retrieved from http://files.eric.ed.gov/fulltext/ED386327.pdf

Bharathi, P. (2014). Self - directed learning and learner autonomy in English language teacher education: Emerging trends. International Journal for Teachers of English, 4(1), 1-6.

Bullock, D. (2011). Learner self-assessment: An investigation into teachers' beliefs. ELT Journal, 62(2), 114-125. https://doi.org/10.1093/elt/ccq041

Camilleri, G. (1997). Learner autonomy: The teachers' views. Retrieved from www.ecml.at/documents/pubCamilleriG_E.pdf

Camilleri, G. (1999). Learner autonomy - The teachers' views. Strassbourg: Council of Europe Publishing.

Candy, P. C. (1991). Self-direction for lifelong learning. California: Jossey-Bass.

Cohen, A. D. (1998). Strategies in learning and using a second language. NY: Addison Wesley Longman Limited.

Cotterall, S. (1995). Readiness for autonomy: Investigating learner beliefs. System, 23(2), 195-206. https://doi.org/10.1016/0346-251X(95)00008-8

Dam, L. (1995). Learner autonomy: From theory to classroom practice. Dublin: Authentik.

Dam, L. (2008). In-service teacher education for learner autonomy. Independence, 43, 21-28.

Dickinson, L. (1987). Self-instruction in language learning. Cambridge: Cambridge University Pres.

Dickinson, L. (1992). Learning Autonomy 2: learner training for language learning. Dublin: Authentik.

Dickinson, L. (1993). Talking shop: Aspects of autonomous learning: An interview with Leslie Dickinson. ELT Journal, 47(4), 330-336. https://doi.org/10.1093/elt/47.4.330 
Duong, T. M. \& Seepho, S. (2014). Promoting learner autonomy: A qualitative study on EFL teachers' perceptions and their teaching practices. Proceedings of the International Conference: DRAL 2 / ILA, 129-137.

Er, K. O. (2014). Balikesir üniversitesi necatibey eğitim fakültesi ingilizce öğretmenliği anabilim dalI öğrencilerinin öğrenen özerkliği konusundaki görüşleri. Balikesir University the Journal of Social Sciences Institute, 17(31), $17-45$.

Erdogan, S. (2003). Learner training via course books and teacher autonomy: A case of need. Retrieved from http://lc.ust.hk/ ailasc/newsletters/onlinepaper/sultan.htm

Finch, A. E. (2000). A formative evaluation of a task-based EFL programme for Korean university students. (Unpublished Ph.D. Thesis. Manchester University, U.K.). Retrieved from http://www.finchpark.com/afe/index.htm

Fumin, F. \& Li Z. (2012). Teachers' roles in promoting students' learner autonomy in China. English Language Teaching, 5(4), 51-56. https://doi.org/10.5539/elt.v5n4p51

Gao, X., \& Zhang, L. J. (2011). Joining forces for synergy: Agency and metacognition as interrelated theoretical perspectives on learner autonomy. In G. Murray, Z. Gao \& T. Lam, T. (Eds.), Identity, motivation and autonomy in language learning (pp. 25-41). Bristol, UK: Multilingual Matters.

Ganza, W.L. (2008). Learner autonomy - teacher autonomy. In T. Lambs \& H. Reinders (Eds.), Learner and teacher autonomy: Concepts, realities and responses (pp.63-79). Amsterdam: John Benjamins Publishing Company. https://doi.org/10.1075/aals.1.081a

Hedge, T. (2000). Teaching and learning in the language classroom. Oxford University Press.

Holec, H. (1979). Autunomy and foreign language learning. Strasbourg: Council of Europe.

Holec, H. (1981). Autonomy in foreign language learning. Oxford: Pergamon Press.

Hurd, S. (1998). Autonomy at any price? Issues and concerns from a British HE perspective? Foreign Language Annals, 31(2), 219-230. https://doi.org/10.1111/j.1944-9720.1998.tb00569.x

Joshi, K. R. (2011). Learner Perceptions and Teacher Beliefs about Learner Autonomy in Language Learning. Journal of NELTA, 16(2), 13-29.

Kumaravadivelu, B. (2001). Toward a postmethod pedagogy. TESOL Quarterly, 35, 537-560. https://doi.org/10.2307/3588427

Khezerlou, E. (2013). Teacher autonomy perceptions of Iranian and Turkish EFL teachers. Journal of HistoryCulture and Art Research, 2(2), 199-211. https://doi.org/10.7596/taksad.v2i2.224

Little, D. (1991). Learner autonomy: Definitions, issues and problems. Dublin: Authentik.

Little, D. (1994). Learner autonomy: A theoretical construct and its practical application. Die Neuere Sprache, 93(5), $430-442$.

Little, D. (2000). Why focus on learning rather than teaching? In D. Little, L. Dam, and J. Timmer (Eds.), Focus on Learning Rather than Teaching: Why and how? Papers from the International association of teachers of English as a foreign language 48 (IATEFL) Conference (Krakow, Poland, May 14-16, 1998). (pp. 3-17). Dublin Ireland: Centre for Language and Communication Studies. Trinity College.

Little, D. (2004). Learner autonomy, teacher autonomy and the European language portolio. Retrieved from http://utc.fr/ untele/2004ppt/handouts/little.pdf

Littlewood, W. (1996). Autonomy: An anatomy and a framework. System, 24(4), 427-435. https://doi.org/10.1016/S0346-251X(96)00039-5

Littlewood,W. (2000). Do Asian students really want to listen and obey? ELT Journal, 54(1), 31-35. https://doi.org/10.1093/elt/54.1.31

Nunan, D. (1999). Second language teaching and learning. Massachusetts: Heinle\&Heinle.

Oxford, R. (1989). The use of language learning strategies: A synthesis of studies with implications for strategy training. System, 12(2), 235-247. https://doi.org/10.1016/0346-251X(89)90036-5

Oxford, R. L. (2001). Teaching English as a second or foreign language. In M. Celce-Murcia (Eds.), Language learning styles and strategies (pp. 359-366). Boston: Heinle\& Heinle/Thomson Learning. 
Oğuz, A. (2013). Öğretmenlerin öğrenen özerkliğinin desteklenmesine ilişkin görüşleri. International Journal of Human Sciences, 10(1), 1273-1297.

Özdere, M. (2005). State-supported provincial university English language instructors' attitudes towards learner autonomy (Unpublished Master's thesis. Bilkent University, Ankara). Retrieved from http://tez2.yok.gov.tr/

Richards, J. C., Gallo, P. B. \& Renandya, W. A. (2001). Exploring teachers' beliefs and the processes of change. PAC Journal. 1(1), 41-58.

Rubin, J. \& Thompson I. (1994). How to be a more successful language learner (2nd Ed.). Boston: Heinle \& Heinle.

Salimi, A. \& Ansari, N. (2015). Learner autonomy: Investigating Iranian English teachers' beliefs. Theory and Practice in Language Studies, 5(5), 1106-1115. https://doi.org/10.17507/tpls.0505.28

Sert, N. (2006). EFL student teachers' learning autonomy. Asian EFL Journal, 8(2), 180-201.

Üstünlüoğlu, E. (2009). Autonomy in language learning: Do students take responsibility for their learning. Journal of Theory and Practice in Education, 5(2), 148-169.

Voller, P. (1997). Does the teacher have a role in autonomous learning? In P. Benson and P. Voller (Eds.), Autonomy and independence in language learning (pp. 98-113). London: Longman.

Wenden, A. (1991). Learner strategies for learner autonomy: Planning and implementing learner training for language learners. UK: Prentice Hall International.

Wenden, A. (1998). Learner strategies for learner autonomy. Great Britain: Prentice Hall.

Yan, H. (2010). Teacher-learner autonomy in second language acquisition. Canadian Social Science, 6(1), 66-69.

Yıldırım, Ö. (2005). ELT Students' perceptions and behavior related to learner autonomy as learners and future teachers (Unpublished M.A. Thesis, Anadolu University, Eskişehir). Retrieved from http://tez2.yok.gov.tr/

Yıldırım, Ö. (2012). A study on a group of Indian English as a second language learners' perceptions of autonomous learning. Turkish Online Journal of Qualitative Inquiry, 3(2), 18-29.

Yumuk, A. Ş. (2002). Letting go of control to the learners: The role of the Internet in promoting a more autonomous view of learning in an academic translation course. Educational Research, 44, 141-156. https://doi.org/10.1080/00131880210135278 